\title{
Spiritualizing Education and Education that is Spiritualized
}

\begin{abstract}
The article, based on the original definition of education, deals with the various circumstances of spiritualizing education, meant as an introduction to functioning within a certain religion, and, with educational introduction to so-called high culture. The paper ends with some remarks about the closeness of high culture and the religious spirit.
\end{abstract}

Keywords: education, spiritualizing education, education that is spiritualized.

\section{Edukacja uduchawiająca a uduchawianie edukacji}

\begin{abstract}
Abstrakt
Artykuł, na bazie autorskiej definicji edukacji, traktuje generalnie o różnych okolicznościach, $\mathrm{z}$ jednej strony edukacji uduchawiającej, jako wprowadzającej do funkcjonowania w obrębie pewnej religii, z drugiej zaś o edukacji, do której wprowadza się tzw. kulturę wysoką, by zakończyć uwagami o bliskości kultury wysokiej i ducha religijnego.
\end{abstract}

Słowa kluczowe: edukacja, edukacja uduchawiająca, uduchawianie edukacji.

Education, when it is understood in a common sense, seems to be a matter clearly "from this world", being assigned to the human condition: to the simultaneous dependence of the human "I" on its "personal" corporeality - open to energy and material inflows from the outside and also outflows, from uni- or bilateral

\footnotetext{
* University of Adam Mickiewicz in Poznan.

Article received: 1.12.2020; accepted: 16.12.2020.
} 
cooperation with other people (symbolic, above all, within culture), and finally from always idiosyncratic, complex, polyphonic, but at the same time monadic "personal" psyche ${ }^{1}$.

Consequently, regardless of whether we adopt - here already scientific - a broad understanding of the term "education" (that includes all factors "introducing" changes in the life of a human individual), or a narrow one (limiting its understanding to premeditated and proactive factors), one may recognize, using only a part of the concept of Kwieciński entitled the "decahedron of education" (Kwieciński 2017: 14-15), that education is being fulfilled, although each time relatively, in a non-absolute shape, in the three dimensions indicated:

- hominization ("mastering" of one's own corporeality, conditioned by the laws of nature);

- psychization (optimization of the subjective "regulation" of various mechanisms of the psyche) and

- socialization ("dealing" with other people).

In turn, this "dealing" with other individuals and/or - through their members - with various human collectives also takes place in three functional areas of collective life:

- economization,

- inculturation and

- politicization,

and therefore it is made as an adaptation (up to submission) to someone else's requirements, and/or as a joint, "democratic" (i.e. with other people) setting of standards for activity and/or as subjugating other people within economic, cultural and/or political relations - from micro- to macro-social human systems.

It is easy to notice that in such an approach the sphere of power and control seems to be central to education in genere, which is expressed in the descriptive metaphors suggested here: mastering (dominating), regulation or dealing with (controlling). Some call this quality par excellence political, while others euphemistically (and perhaps rightly sometimes): culture, i.e. arbitrarily defined elevation - educational elevation of a less "mature" person, and according to the chosen criteria, to a "higher", more refined level of humanity (Boroch 2013).

At the beginning of the issue at hand, the epistemological objection, expressed in the first sentence of this text, and namely "it seems", appears to be truly significant. It is an expression of a rational, probably unchangeable presumption in the said case, which, following Emil du Bois-Reymond, we should classify not only as

\footnotetext{
1 The possessiveness implied by terms such as "own" or "personal" is the result of the clumsiness of language to convey the nature of the relations in question. As yet, there are no more adequate terms. Moreover, ideological usurpations of the same kind are present today, e.g. in numerous slogans, such as "My body - my business", with the obvious absence of ownership titles among self-proclaimed "owners", and additionally in the absence of effective means of controlling such "owners" over "owned" in a number of important physiological mechanisms.
} 
ignoramus but also ignorabimus ${ }^{2}$. Not only did we not find it out so far, but we will probably never know it fully. The open questions here are, when taken seriously, the metaphysical - i.e. going beyond the physical - the spiritual part and the spiritual context of human existence ${ }^{3}$.

Despite the doubts expressed by some (surely not all) scientists and nonscientific skeptics, at least $83.7 \%$ of today's humanity believe in a personal God, more numerous Gods, impersonal spiritual energy, multiple spiritual forces or Logos - the cosmic Reason 4 .

Besides, so to speak, the Creator, who is possibly - for non-deists - also the Determinator (or - according to a religion - their positively cooperating team or antagonistic system) of the human world and the universe in general, the "spiritual world", as a space or spaces sui generis, is/are "populated" (although the latter is an awkward anthropomorphization, instead of which it would be more appropriate to use the Latin term: "animated") 5 by spiritual intermediate beings, sometimes of some hierarchical orders, and also by quite common spiritual beings - "functionaries" and "citizens" of that "other world" with its different functionalities, because there are essentially different spiritual "environments" there.

Spiritual beings or instances may, as a long series of reports, contained in religious texts both and in reports from private "revelations", shows, contact more or less directly with living people and/or influence the lives of the latter, also in the strict sense the education, and most importantly, they are to decide - at least to some extent - about the form of human duration during and after life (or between successive lives, as in the case of metempsychosis assumed in some religious systems).

A common problem for people is the relative uniqueness of direct contacts, both in physical and metaphysical space, with spiritual beings and spaces. The lack of such experiences for the vast majority of people makes it more difficult to establish a relationship with the spiritual sphere, and especially to seriously engage in it. Therefore, other people or information artifacts of their authorship become indispensable in this respect, pointing to and bringing spirituality closer.

Being brought closer to the spiritual sphere and the resulting subjective identification with it by others takes place in the acts of communication and/or as a result of it, while such communication is not limited to the transfer of infor-

\footnotetext{
2 "We do not know and we will not know" - a summary of the speech entitled "The Limits of Science", delivered at the Congress of Science and Medicine in 1872 - See e.g. https://en.wikipedia.org/wiki/ Ignoramus_et_ignorabimus

3 The concept of "spirituality" excludes non-religious psychological connotations (some kind of individual advancement in psychological development), as well as social ("spiritualising" a given community or the whole globe - See: German ideas of the "spirit of the nation", "spirit of the world", "spirit of the times" or the Gaia hypothesis).

${ }^{4}$ Figures given after: https://www.pewforum.org/2012/12/18/global-religious-landscape-unaffiliated/

5 Latin: anima.
} 
mation, but also to other forms of cooperation in relation to the sacrum, such as participation in liturgies, community rites, etc.

Education as a specific type of communication, in which is favoured (often also with the use of compulsion) "acquiring" by the educated the "proper": knowledge, skills and attitudes, is widely present in the world as "religion classes" - a spiritual formation, suitable for - legal in a given country - types of faiths and their relationships with schools as institutions of legitimate education.

Here we find various formal and legal configurations of the presence of religion in schools. In today's conditions of different states functioning, their legal foundations are factors that determine various qualities of religious education.

Within the international range, with regard to the above-mentioned regulations, let us first recall Art. 18 of the Universal Declaration of Human Rights, as the main international agreement in this respect, which recognizes the right of people to freedom in the field of religion ${ }^{6}$, to freely change it (sic! $)^{7}$ and manifest it in the form of teaching, religious practice, worship and rituals.

This right to teach, and thus to receive religious education, applies to all human subjects - individually and as a group - but it is worth making some logical points here.

Firstly, large religious communities (although they are internally diverse, too), such as Christian, Islamic or Buddhist ones, are specially adapted to lead such educational activities, and have their appropriate infrastructures (also in the field of electronic media) and professional educators.

However, in order for education understood as cultural transmission, and here in the form of a religious propaedeutics, to take place, it is enough to have an appropriate "religious knowledge" and the will to pass it on to others on the part of at least one "knowing" person (the origin, and hence the reliability of such "knowledge" is a matter of less importance here). Each one, even the smallest religious group (called sometimes a "sect") begins with a person who has actively accessed or who (passively on his part) has been given the opportunity to learn about spiritual secrets, and even from one who himself calls himself a representative of the spiritual world. It is not surprising then that in the United States of America alone over 300,000 various religious groups are registered today ${ }^{8}$.

In Poland, the constitutional regulations in the extensive Art. 53 determine the possible forms of connections between citizens' religious activity and compulsory

\footnotetext{
${ }^{6}$ See e.g. https://www.unic.un.org.pl/documents/declaration.php. Quite a special formal solution in this article (and in only the next two of them) is the link between law and freedom - after all these are synonyms (see e.g. https://www.thesaurus.com/browse/right?s=t), which the logical possibility of opposite formulas, i.e. there is neither the "right to be coerced" nor the "freedom to be deprived of the right to something" (except for the case of masochism).

7 Stressing in the text of this article the possibility of making changes in this respect is logically redundant, because freedom means at the same time: the ability to accept and commit to a particular religion, change it at will to other religions, as well as the possibility of refusing to be a follower of any religion.

${ }^{8}$ Data after estimations for the year 2010 - http://www.usreligioncensus.org/
} 
education (in schools) and the non-compulsory, emphasizing on the one hand (in conjunction with Art. 48), parental rights in this respect towards children, and stipulating on the other that in the case of the children themselves their personal freedom of religion is valid, although related (but without any necessary legal precision) to honouring the maturity of these children ${ }^{9}$.

Still other aspects of the legitimate relationships between education and religion are specified in Art. 14 of the Charter of Fundamental Rights of the European Union according to which citizens of EU countries have the possibility to establish educational institutions (and thus also denominational schools), and the religious and pedagogical beliefs of parents of these countries are to be respected when it concerns the upbringing and teaching of their children ${ }^{10}$.

A special case in the latter reference is so-called home education. The majority of parents choosing to educate their children on their own are parents who are religiously motivated to choose such an option, not finding appropriate religious schools in the immediate vicinity of their home or who are critical of the educational offers of those schools.

The above-mentioned provisions of the Charter of Fundamental Rights constitute the appropriate legal framework here as well. Unfortunately, these educational parental powers are limited in the same Charter article by the national legal provisions. Consequently, in the countries where the state does not legalize home education, such rights do not exist. This is the case, for example, in Germany and Sweden, and also France, where under the pretext of combating radical, separatist Muslim education, the legal possibility of teaching at home will be eliminated from the beginning of the next school year ${ }^{11}$.

Here, once again, the dependencies of religious education organized by adults on the general living conditions of a given society - political, above all, but also economic and cultural, on the curriculum content, forms of educational organization, methods and didactic means used in such education, and finally on - appearing to be equally important - the personal factors of a religiously educated child and teenager.

Possible collisions between the religious educational offer and the psyche and behaviour of today's student may determine the effectiveness of the religious message. Bradley, an American pastor, has written a book on the mistakes made by parents in educating their children in introducing the latter into the sphere of a given religion. Such errors, often with serious life consequences for all family members, are:

- selfish, compensatory parental dreams to be fulfilled by children;

- making an idol of the family;

\footnotetext{
${ }^{9}$ See https://www.sejm.gov.pl/prawo/konst/polski/kon1.htm

${ }^{10}$ See: https://eur-lex.europa.eu/legal-content/PL/TXT/PDF/?uri=CELEX:12016P/TXT\&from=DE

${ }^{11}$ See e.g. "French parents are to be banned from home-schooling their kids as part of Emmanuel Macron's fight back against Islamic extremism" - https://www.dailymail.co.uk/news/article8964325/Home-schooling-BANNED-France-Macrons-fight-against-Islamic-extremism.html
} 
- placing undue emphasis on external forms of religiosity;

- tendency to judge a child;

- excessive reliance on authority and control;

- exaggeration in protecting the child from bad influences from the outside and

- blindly following the rules from guides on adequate parenting (Bradley 2006).

It is also worth considering at this point the possible supplementation of educational forms of impropriety, above-mentioned, and committed by parents, taking into account not only the excesses, but also deficiencies in certain areas of parental religious education, and also evident errors in the perception of what would be appropriate within it finally, ending in adoption of parasitic solutions, and especially predatory ones in a deliberate way that destroys the child.

It is also very obvious that out-of-family teachers of religion - be they school or community teachers - can also generate negative educational influences by committing specific improprieties.

This does not mean, however, that education introducing people into spirituality takes mostly negative shapes. Many of the messages of this kind hit the pedagogical heart, because the interpersonal relationships that accompany them are adequate to the needs of the people participating in them, just as the means of education used in them are similarly adequate.

The second of the directions indicated in the title of this article, which is adopted in education in the face of the challenge of "spirituality", is entering into it, i.e. to education, the said "spirituality". Here, however, it would be difficult to understand this orientation as saturating with religious elements the "earthly", regular education in schools and other educational environments. In this case, it is rather about introducing to educational programs such content of education that belongs to the so-called high, elitist culture as opposed to egalitarian popular culture and economic and political utilitarianism.

Since the creators of state educational programs, in Poland the so-called "core curricula", establishing the framework and, at the same time, the educational requirements for all institutional entities in compulsory education, are, to a large extent, selected politically by state educational authorities, creators of works of high culture, i.e. scientists and artists, the required forms of collective education depend on their understanding of the "canon of high "culture", appropriate for a given field (however, constantly limited by the ideological preferences of situational subjects of macro-educational decisions).

It should be added that the scope of autonomy in determining the realities of promoting "high culture" in schools for teachers themselves is relatively narrow, being determined on the one hand individually, by the level of determination to possibly resist the state requirements of cultural "right" education, and on the other hand by the level of the assertiveness of parents of their students to eliminate "undesirable" school curriculum content. 
The latter most often concerns the ideologically and axionormatively saturated content of humanistic and social subjects (although the former are also necessarily social), in contrast to the "indisputable" and "truly scientific" content of science subjects. The objections expressed here by the use of quotation marks point in the direction of overlapping also on the basis of the second group of the mentioned sciences, the politically grounded arbitrariness in deciding what is compatible and what is not with the essence of science as such.

Otherwise, the ambitions of the promoters of such "high cultures" often exceed the limits of reason, both in terms of size and the level of advancement of knowledge and skills, and the depth of involvement of the average student in the field of science and/or art by the promoters of those culture domains represented.

At this point, it is worth recalling the critical opinions of Mazur's (not excessive in volume and sophistication) requirements of the state school curriculum. He, the founder of the Polish school of qualitative cybernetics in a series of articles on the content and forms of education in Polish schools, emphasized that from the point of view of real life usefulness, as much as $95 \%$ of the content planned to be covered at schools (especially in the field of "natural sciences") is unacceptable ${ }^{12}$.

Critics of public education, such as John Taylor Gatto, go even further, recognizing that the general forms and content imposed on public education recipients are not intended to elevate them to a higher level of culture, but rather their (read: essentially mental) "overwhelming" with excessively refined content, in the morally anti-human conditions of school functioning (Gatto 2000). The latter, in addition to the intellectual daze, bring about the effect of "de-moralization" that breaks down natural interpersonal bonds.

It is against such a background that culture seems to reveal its humanistic essence - its Janus faces of nobility: it is the nobility of the mind inseparably linked with the nobility of the heart.

Perhaps an indication toward the very culture, is the culture of a "pedagogical province" from the prophetic world of Hermann Hesse's Glass Bead Game. Let us recall its sparse, original image:

The Glass Bead Game is thus a mode of playing with the total contents and values of our culture; it plays with them as, say, in the great age of the arts a painter might have played with the colors on his palette. All the insights, noble thoughts, and works of art that the human race has produced in its creative eras, all that subsequent periods of scholarly study have reduced to concepts and converted into intellectual property - on all this immense body of intellectual values the Glass Bead Game player plays like the organist on an organ. And this organ has attained an almost unimaginable

\footnotetext{
${ }^{12}$ Here is mentioned an eight-part series of articles entitled $O$ szkole cybernetycznie, published in 1965/1966 in the journal "Argumenty".
} 
perfection; its manuals and pedals range over the entire intellectual cosmos; its stops are almost beyond number. Theoretically this instrument is capable of reproducing in the Game the entire intellectual content of the universe ${ }^{13}$.

And although the players in the game of glass beads may be (because it is a matter of the distant future) only people who have undergone the appropriate spiritual formation, their cultural artistry is also to be enjoyed during public games by people who are much less spiritually advanced, but who highly value spirituality.

Perhaps a certain real precedent for such a forward-looking vision is the sympathy of ordinary Italians for the art of opera, hermetic to its core.

All we need here is an appropriate... and nomen omen "pedagogical culture". The motivation of the greater part of members of a society to engage in high culture seems to depend on the quality of the pedagogical message of the whole society. Cultural "spirituality" is therefore not easy, because the level of "spirituality" offered by public education is as we know it. Again, we are dealing with excesses, insufficiencies, lacks, errors and deliberate destruction strategies.

Finally, it is worth considering the logically possible relationships between the two directions of education just analysed in this text. So are there any closer connections between religious education and general cultural spiritualization, and between educational introduction to high culture and religious "spiritualization"?

As for the first possibility, of course, and regardless of the solutions of eliminating politically incorrect (heretical) manifestations of culture, which are sometimes called the "war of fasting against carnival", there are many examples of inducing interest in various forms of high culture and mastering them when introducing religious content. An example here is consumers' interest in many varieties of visual or literary arts, as well as artistic involvement in them among many believers, sometimes ironically ending with abandoning religion itself. The same happened with the transitions from given theological approaches to reality to different theological or philosophical reconstructions thereof, leading either to a new religious commitment (see Martin Luther's case) or to apostasy (abandonment of faith or religion).

Many, not only clerical and secular authors of religious works (and thus educational messages of this kind) were also authors in advanced cultural forms, valued even by religiously disengaged people. Among them were, for example, St. Thomas Aquinas, a significant philosopher, poet and priest Jan Jakub Twardowski, or scientists, such as the late biologist Fr. Włodzimierz Sedlak and the still active physicist and theologian, Fr. Michał Heller, emphasizing that the findings of even such a sophisticated materialistic field of science as physics can be rationally associated with a religious-type spirituality (Heller 2016: 327).

\footnotetext{
${ }^{13}$ See: https://archive.org/stream/MagisterLudi-TheGlassBeadGame-HermanHesse/hesseludi_djvu.txt. It's the translation by Richard and Clard Winston (1943).
} 
Can literally "cultural" education also lead to spirituality? It seems the obvious answer is "yes". Philosophical considerations, scientific reflections and spiritual experiences (not necessarily related to age and health condition) of many atheists (even those brought up in the spirit of atheism) led them to the recognition of the necessity of faith, although not always institutionally defined. Here, for example, we can list such people as: Eben Alexander (neurosurgeon), Mark Zuckerberg (the creator of Facebook), Salvador Dali (artist), Gabriel Marcel (philosopher), Victor Turner (cultural anthropologist), Sigrid Undset (writer), Maurice Béjart (ballet), Aleksander Solzhenitsyn (dissident writer), Francis Collins (geneticist, manager of the Human Genome Project) and Johnny Lang (rock and blues musician, originally declaring hatred of Christianity, a convert due to his personal revelation) ${ }^{14}$.

There is one more possibility in this respect, which, among other pertinent remarks, was proposed by the well-known director of Russian cinema, a representative of poetry cinema, Andrei Tarkovsky, who was also previously a convert. In the report from the meeting with the author, the interviewer with the artist, Jerzy Illg, describes Tarkovsky's statements about the relationship between art and religion in these words:

Culture cannot exist without religion. In a sense, culture sublimates into religion, and religion expresses itself in culture. [Culture without religion dies. A society devoid of religion becomes devoid of ideals, it has no ideals, but plans, that can be realized or not only.] Culture and art are inextricably linked with the spiritual realm, and this is born of religion. (...) For me, the problems of religion are not only a personal matter, they are a matter of our civilization and culture (Tarkovsky 2016: 33).

At the same time Tarkovsky emphasizes that real art is elitist:

Great art, great works have never satisfied the tastes of the public. Art cannot be a banality available to everyone, because it would cease to be art, it would cease to provide ideals and spiritual values (ibidem: 40).

It is so because of a certain "poetry and subtlety", perhaps also "elusiveness" of great art, features which Tarkovsky ascribes to Chopin's music (ibidem: 92).

And complaining about the inhabitants of the satiated West, the director concludes:

They do not understand that I am talking about spirituality in the sense that a person should know what he is living for, should think about the meaning of life. Whoever started to think about it was, in a sense, enlight-

\footnotetext{
${ }^{14}$ See: https://en.wikipedia.org/wiki/List_of_former_atheists_and_agnostics
} 
ened by some spiritual light, he would not forget this problem, he would not leave it, he had already embarked on a path (ibidem: 92).

For the remaining people

(...) there are absolutely no problems with the human soul or any moral effort that a person should undertake during his life (ibidem).

Everything that has been said above about the relationship between education and spirituality is, therefore, a question of discovering the meaning, also inherent in the well-known phrase from the Gospel according to St. Matthew: "Man does not live on bread alone (...)"15.

It seems that the search for this meaning must also be encouraged in education!

\section{References}

Boroch, R. (2013) Kultura w systematyce Alfreda L. Kroebera i Clyde'a Kluckhohna, Warszawa, BEL Studio.

Bradley, R. (2006) Solving the Crisis in Homeschooling: Exposing seven major blind spots of homeschoolers, CreateSpace Independent Publishing Platform.

Gatto, J. T. (2000) The Underground History of American Education: A Schoolteacher's Intimate Investigation Into the Problem of Modern Schooling, Odysseus Group.

Heller, M. (2016) Wierzę, żeby zrozumieć, rozmawiają Wojciech Bonowicz, Bartosz Brożek, Zbigniew Liana, Kraków, CC Press. Znak, p. 327.

Kwieciński, Z. (2017) The Sociopathology of Education, Wrocław, Wydawnictwo Naukowe Dolnośląskiej Szkoły Wyższej.

Tarkowski, A. (w rozmowie z Jerzym Illgiem i Leonardem Neugerem). Zwierciadło (2016), Kraków, Wydawnictwo Znak.

\section{Online sources}

http://www.usreligioncensus.org/ [date accessed: 27.11.2020].

https://archive.org/stream/MagisterLudi-TheGlassBeadGame-HermanHesse/ hesseludi_djvu.txt [date accessed: 27.11.2020].

\footnotetext{
${ }^{15}$ See e.g. https://biblehub.com/matthew/4-4.htm
} 
https://biblehub.com/matthew/4-4.htm [date accessed: 27.11.2020].

https://en.wikipedia.org/wiki/Ignoramus_et_ignorabimus [date accessed: 27.11.2020].

https://en.wikipedia.org/wiki/List_of_former_atheists_and_agnostics [date accessed: 27.11.2020].

https://eur-lex.europa.eu/legal-content/PL/TXT/PDF/?uri=CELEX:12016P/TXT\& from=DE [date accessed: 27.11.2020].

https://www.dailymail.co.uk/news/article-8964325/Home-schooling-BANNEDFrance-Macrons-fight-against-Islamic-extremism.html [date accessed: 27.11.2020]. https://www.pewforum.org/2012/12/18/global-religious-landscape-unaffiliated/ [date accessed: 27.11.2020].

https://www.sejm.gov.pl/prawo/konst/polski/kon1.htm [date accessed: 27.11.2020]. https://www.unic.un.org.pl/documents/declaration.php [date accessed: 27.11.2020]. 